\title{
Coriolus Versicolor Extract
}

National Cancer Institute

\section{Source}

National Cancer Institute. Coriolus Versicolor Extract. NCI Thesaurus. Code C78184.

An extract derived from the mushroom Coriolus versicolor, containing polysaccharide $\mathrm{K}$ (PSK) and polysaccharide-peptide (PSP), with potential immunomodulating and antineoplastic activities. Coriolus versicolor extract has been shown to stimulate the production of lymphocytes and cytokines, such as interferons and interleukins, and may exhibit antioxidant activities. However, the precise mechanism of action(s) of this agent is unknown. 